\title{
Hormesis with glyphosate depends on coffee growth stage
}

\section{LEONARDO B. DE CARVALHO ${ }^{1}$, PEDRO L.C.A. ALVES ${ }^{2}$ and STEPHEN O. DUKE ${ }^{3}$}

\author{
${ }^{1}$ Departamento de Agronomia, Centro de Ciências Agroveterinárias, \\ Universidade do Estado de Santa Catarina, Av. Luiz de Camões, 2090, 88520-000 Lages, SC, Brasil \\ ${ }^{2}$ Departamento de Biologia Aplicada à Agropecuária, Faculdade de Ciências Agrárias e Veterinárias, \\ Universidade Estadual Paulista, Via de acesso Prof. Paulo Donato Castellane, s/n, 14884-900 Jaboticabal, SP, Brasil \\ ${ }^{3}$ Agricultural Research Service, United States Department of Agriculture, \\ Natural Products Utilization Research Unit, P.O. Box 8048, University of Mississippi, Oxford, MS 38677, USA
}

Manuscript received on September 24, 2011; accepted for publication on August 27, 2012

\begin{abstract}
Weed management systems in almost all Brazilian coffee plantations allow herbicide spray to drift on crop plants. In order to evaluate if there is any effect of the most commonly used herbicide in coffee production, glyphosate, on coffee plants, a range of glyphosate doses were applied directly on coffee plants at two distinct plant growth stages. Although growth of both young and old plants was reduced at higher glyphosate doses, low doses caused no effects on growth characteristics of young plants and stimulated growth of older plants. Therefore, hormesis with glyphosate is dependent on coffee plant growth stage at the time of herbicide application.
\end{abstract}

Key words: Coffea arabica L., weed management, herbicide, spray drift, stimulatory effect.

\section{INTRODUCTION}

Coffee is one of the world's most popular beverages (Fujioka and Shibamoto 2008) and the most important traded commodity in the world after oil (Naidu et al. 2008). Brazil, where coffee production is of economic as well as social importance, is the main world producer (Marana et al. 2008). Among coffee tree species planted in Brazil, Coffea arabica L. has the highest economic importance, producing the consumers' favorite coffee drink (Nascimento et al. 2006).

An important issue for coffee production is weed management. Brazilian growers commonly use inter-row mechanical weeding associated with intrarow chemical control. So, herbicides can reach coffee

Correspondence to: Leonardo Bianco de Carvalho

E-mail:1bcarvalho@cav.udesc.br plants both directly by accidental application and indirectly by spray drift, as in other crops such as citrus and eucalyptus where similar weed management is used (Tuffi Santos et al. 2006, Gravena et al. 2009, Machado et al. 2010).

The main herbicide used in Brazilian coffee plantations is glyphosate ( $N$-(phosphonomethyl) glycine). Effects of glyphosate on plants are well understood, but its growth-promoting effects (hormesis) at very low doses have not been well studied. Researchers have reported growth-promoting effects of low glyphosate doses on different plant species (e.g., Cedergreen et al. 2007, Velini et al. 2008, Cedergreen and Olesen 2010). Hormesis can be defined as an adaptive response characterized by biphasic dose responses of generally similar 
quantitative features with respect to amplitude and range of the stimulatory response that are either directly induced or the result of compensatory biological processes following an initial disruption in homeostasis (Calabrese and Baldwin 2002), although the mechanism(s) of hormesis is poorly understood.

Some previous experiments indicate that $C$. arabica plants show some tolerance to herbicide glyphosate. This indicates that coffee plant growth cannot be reduced by glyphosate reaching the crop due to spray drift from application to weeds at doses that kill weeds. But, if accidental direct application occurs, plant growth could be reduced. We hypothesize that glyphosate hormesis in coffee plants is dependent on the growth stage at which the plant is sprayed. Thus, the objective of this research is to evaluate if there is any effect on C. arabica plants exposed to glyphosate at two distinctly different plant growth stages.

\section{MATERIALS AND METHODS}

Plant Material AND GROWING CONDITIONS

Greenhouse experiments were carried out in Jaboticabal, SP, from October 2009 to February 2010. Five-leaf seedlings of C. arabica cv. Catuaí Vermelho IAC-144 were transplanted to 7-L pots filled with a substrate containing a mixture of manure and Red Latosol clay textured $(1: 3, \mathrm{v} / \mathrm{v})$ with $\mathrm{pH}\left(\mathrm{CaCl}_{2}\right)=5.1$, O.M. $=20.0$ g. $\mathrm{dm}^{-3} ; \mathrm{P}$ $($ resin $)=26.0 \mathrm{mg} \cdot \mathrm{dm}^{-3}, \mathrm{~K}=1.9, \mathrm{Ca}=23.0, \mathrm{Mg}$ $=14.0, \mathrm{H}+\mathrm{Al}=25.0, \mathrm{SB}=38.9$, and $\mathrm{T}=63.9$ $\mathrm{mmol}_{\mathrm{c}} \cdot \mathrm{dm}^{-3}$, and $\mathrm{V}=61 \%$. Plants were fertilized with 3 g.pot ${ }^{-1}$ of NPK (4-14-8) fertilizer just after transplanting. Water was supplied every day. Fungicides (piraclostrobin, epoxiconazol, and cooper oxichloride) and insecticide (thiamethoxan) were applied every two weeks.

\section{HERBICIDE AND APPLICATION CONDITIONS}

A formulation of glyphosate with $48 \% \quad(\mathrm{~m} / \mathrm{v})$ of active ingredient [isopropylamine salt of $N$-(phosphonomethyl)glycine] and $36 \%$ of acid equivalent (AE) of glyphosate was used. Herbicide was applied using a $\mathrm{CO}_{2}$-pressurized sprayer with flat plan nozzles (TeeJet, 80.02, USA), pressure of 1.90 kgf.cm ${ }^{-2}$, and volume of application of 200 L.ha ${ }^{-1}$.

\section{Treatments And EXPERIMENTAL Design}

Treatments were $0,180,360,720,1,440$, and 2,880 g.AE.ha ${ }^{-1}$ of glyphosate, sprayed directly on coffee plants, simulating drift and accidental application conditions. Applications were made at 10 and 45 days after transplanting (DAT). Experiments were set up in a factorial scheme with two main treatments (time of glyphosate application) and six secondary treatments (glyphosate doses). A completely randomized design was used with six replicates. Each experiment was repeated at least twice.

\section{EVAluation Time AND MEASUREd CHARACTERISTICS}

All experiments were evaluated at 60 days after herbicide application (DAA) when plant height, stem diameter (Zaas Precision, $150 \mathrm{~mm}$, Brazil), leaf number, leaf area (Li-Cor Inc., LI3000A, USA), and stem and leaf dry mass after drying for $96 \mathrm{~h}$ in a forced air oven at $70^{\circ} \mathrm{C}$ were measured.

\section{Statistical AnAlysis}

There was no interaction between treatments and experimental repetitions detected by an ANOVA test (data not shown), so all data were pooled across experimental repetitions for further analysis and presentation. Data of plants with 10 DAT were submitted to a nonlinear regression analysis, according to the equation:

$$
\mathrm{Y}=\mathrm{Y} 0+\mathrm{A} /(1+\exp (-(\mathrm{X}-\mathrm{X} 0) / \mathrm{B}))
$$

where: $\mathrm{Y}$ describes a coffee characteristic evaluated in response to $\mathrm{X}$, representing the glyphosate doses; Y0 describes the bottom value while A represents the top value of the coffee characteristic; X0 describes the dose reducing the coffee characteristic by $50 \%\left(\mathrm{I}_{50}\right)$; and $\mathrm{B}$ is the slope of the curve. 
Data of plants with 45 DAT were submitted to nonlinear regression analysis, according to the equation:

$$
\mathrm{Y}=\mathrm{Y} 0+\mathrm{A}^{*} \exp \left(-0,5^{*}((\mathrm{X}-\mathrm{X} 0) / \mathrm{B})^{2}\right)
$$

where: $Y$ describes a coffee characteristic evaluated in response to $\mathrm{X}$, representing the glyphosate doses; Y0 describes the bottom value while $\mathrm{A}$ is the difference between $\mathrm{Y} 0$ and the maximum $\mathrm{Y}$ value of the coffee characteristic; $\mathrm{X} 0$ describes the dose promoting the highest stimulation in the coffee characteristic; and B is the standard deviation on $\mathrm{X} 0$.

The dose reducing coffee characteristic by $50 \%\left(\mathrm{I}_{50}\right)$ of plants with 45 DAT was calculated based on the adjusted equations when the growth characteristics were reduced by $50 \%$ when comparing to the no-treated check.

Regression analyses were performed using SigmaPlot software (Systat Software Inc., Version 10.0, USA).

\section{RESULTS}

Coffee plants exposed to the highest glyphosate dose at 10 and 45 DAT showed reduction of all growth characteristics. In 10-DAT plants, plant height, stem diameter, leaf number, leaf area, stem dry mass, leaf dry mass, and above ground dry mass were reduced by $9,12,30,53,31,50$, and $44 \%$, respectively, whereas, in 45 DAT-plants, those same characteristics were reduced by 11,12 , $18,42,36,44$, and 40\%, respectively (Figures 1-5).

When applied at 10 DAT, the only effect of glyphosate on plant height was inhibition at the two highest doses (Figure 1A). Similar results were observed on stem diameter (Figure 2A), leaf number (Figure 3A), leaf area (Figure 4A), stem dry mass (Figure 5A), leaf dry mass (Figure 5C), and above ground dry mass (Figure 5E) of coffee plants that were exposed to glyphosate application at the same growth stage. Stem diameter was more sensitive to glyphosate than the other growth parameters. On the other hand, stimulatory effects of low doses of glyphosate were measured on all coffee plant growth characteristics after exposure to glyphosate at 45 DAT. Maximum stimulatory effects of $21 \%, 18 \%$, $28 \%, 39 \%, 24 \%, 31 \%$, and $27 \%$ were observed on plant height, stem diameter, leaf number, leaf area, stem dry mass, leaf dry mass, and above ground dry mass when coffee plants were exposed to 738, 416, 620, 536, 488, 530, and 513 g.AE.ha ${ }^{-1}$, respectively (Figures 1B, 2B, 3B, 4B, 5B, 5D, and $5 \mathrm{~F}$, respectively), characterizing a hormetic effect.
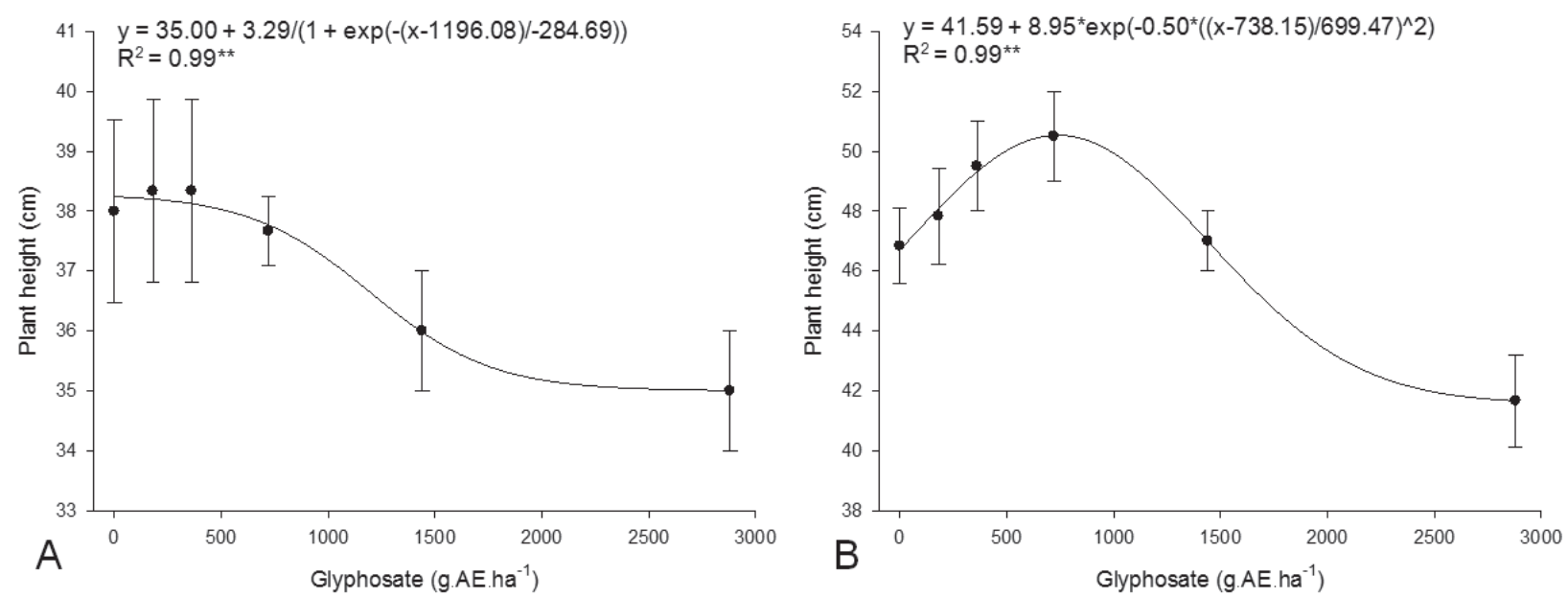

Figure 1 - Coffee plant height at 60 days after being exposed to glyphosate applied on plants with 10 (A) and 45 (B) days after transplanting. Jaboticabal, 2009-10. Vertical bars indicate standard error of the mean, ${ }^{* *}$ significant at $p<0.01$. 

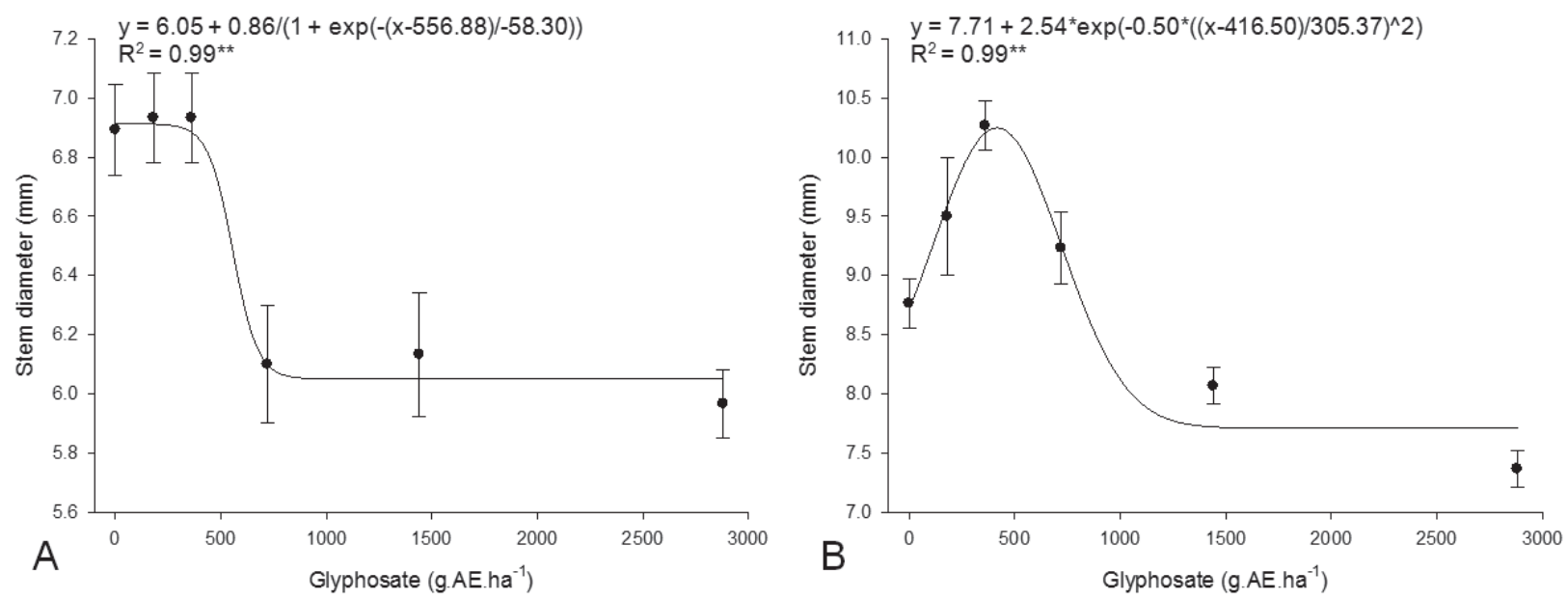

Figure 2 - Coffee stem diameter at 60 days after being exposed to glyphosate applied on plants with 10 (A) and 45 (B) days after transplanting. Jaboticabal, 2009-10. Vertical bars indicate standard error of the mean, $* *$ significant at $p<0.01$.
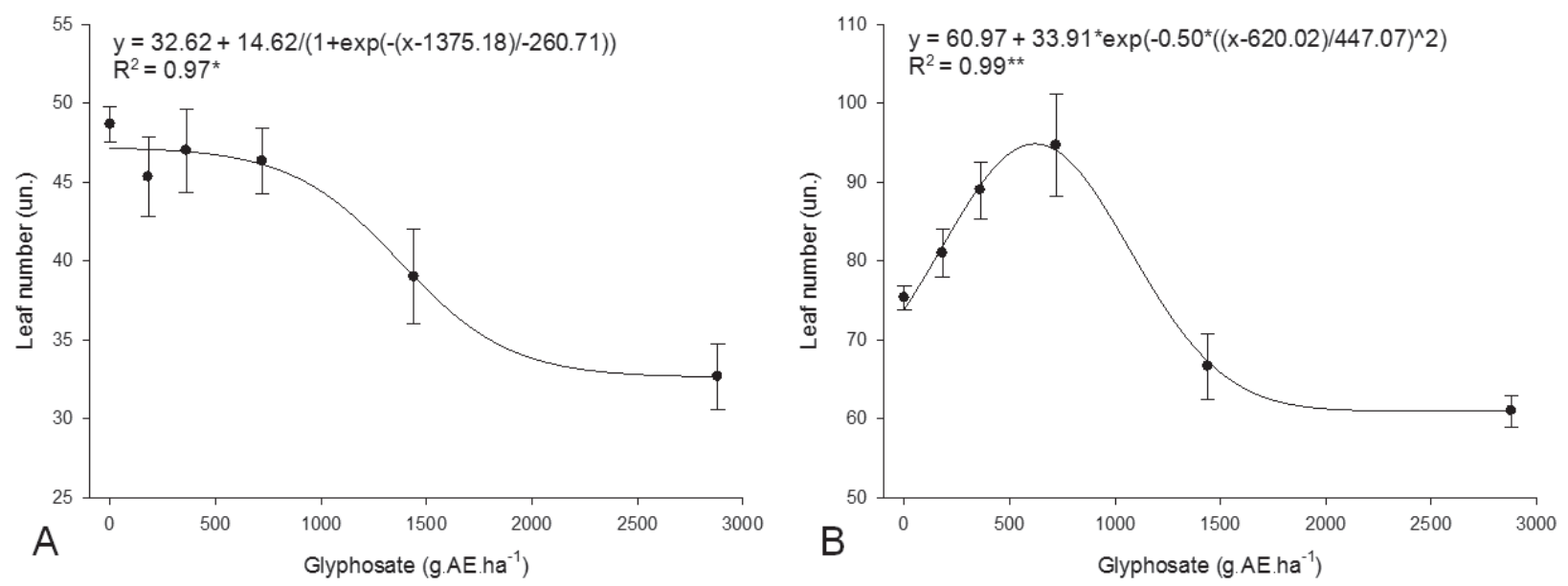

Figure 3 - Coffee number of leaves at 60 days after being exposed to glyphosate applied on plants with 10 (A) and 45 (B) days after transplanting. Jaboticabal, 2009-10. Vertical bars indicate standard error of the mean, * $* *$ significant at $p<0.05$ and $p<0.01$, respectively.

\section{DISCUSSION}

We assume that reductions in plant height, stem diameter, leaf number, leaf area, stem dry mass, leaf dry mass, and above ground dry mass observed in coffee plants treated with high doses of glyphosate at 10 and 45 DAT occurred due to inhibition of 5-enolpyruvylshikimate-3-phosphate synthase (EPSPS) (EC 2.5.1.19) of the shikimate pathway. Inhibition of of EPSPS results in reduction in synthesis of of EPSP and metabolic products of EPSP, such as the aromatic acids phenylalanine, tyrosine, and tryptophan that are required for protein synthesis (Siehl 1997, Herrman and Weaver 1999), as well as indoleacetic acid, lignin, and many secondary compounds required for plant defence and other aspects of chemical ecology (Lydon and Duke 1989). Deregulation of the shikimate pathway also causes shortages of compounds necessary for carbon fixation (Siehl 1997), a process that is quickly inhibited by glyphosate (Servaites et al. 1987). These metabolic changes cause plant growth reduction and even plant death when the 

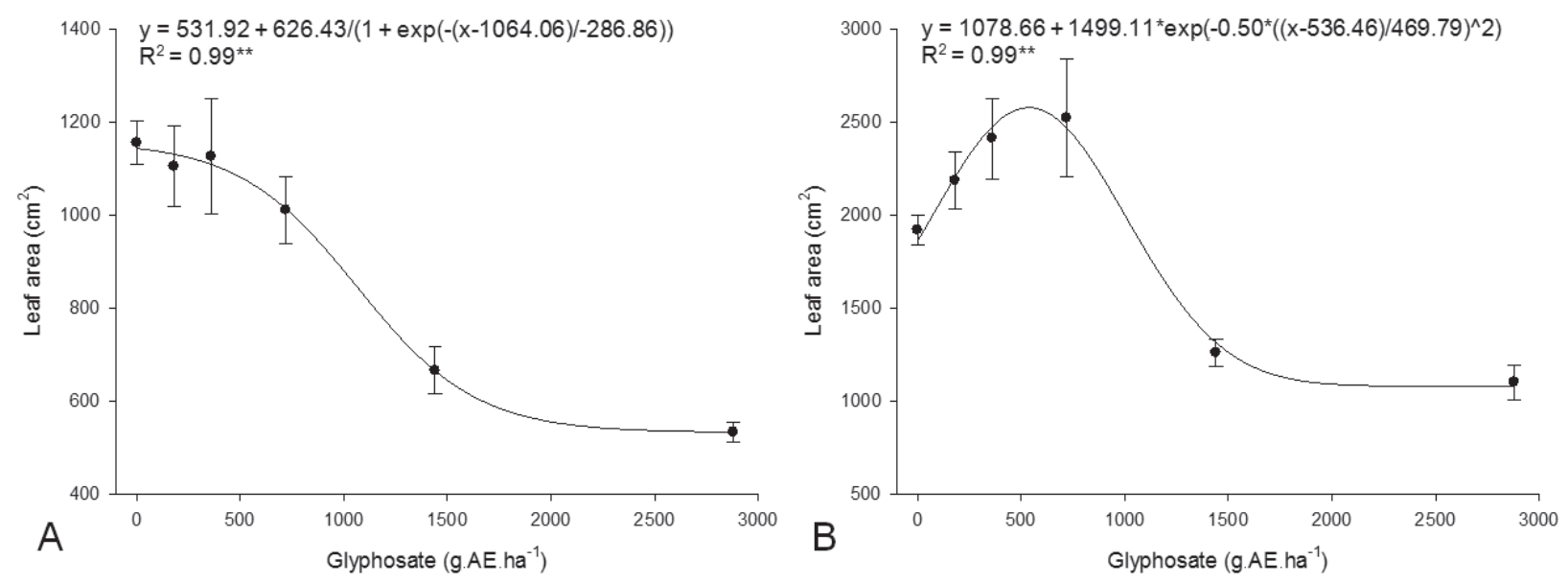

Figure 4 - Coffee leaf area at 60 days after being exposed to glyphosate applied on plants with 10 (A) and 45 (B) days after transplanting. Jaboticabal, 2009-10. Vertical bars indicate standard error of the mean, $* *$ significant at $p<0.01$.

herbicide is applied to glyphosate-sensitive plants at a susceptible growth stage. Coffee plants at both growth stages of this study tolerated lower glyphosate doses and, when applied at 45 DAT, grew even more rapidly after exposure to low glyphosate doses.

The hormetic effect of glyphosate has also been observed in the growth of Abutilon theophrasti Medik., Commelina benghalensis L., Echinochloa crus-galli (L.) P.Beauv., Eucalyptus grandis Hill Ex. Maiden, Glycine max (L.) Merr., Hordeum vulgare L., Pinus caribea L., Stellaria media (L.) Vill./Cyr., Tripleurospermum inodorum (L.) Sch. Bip., Saccharum spp., and Zea mays L. plants (Schabenberger et al. 1999, Wagner et al. 2003, Cedergreen et al. 2007, Velini et al. 2008, Silva et al. 2009, Cedergreen and Olesen 2010, Bott et al. 2011).

The mechanism of the stimulatory effect is not well understood, and few studies have suggested a molecular mechanism of hormesis in plants (as reviewed by Cedergreen et al. 2007). Both Velini et al. (2008) and Cedergreen and Olesen (2010) indicate that the hormetic effect is in some way related to partial inhibition of EPSPS at low glyphosate doses. The absence of any growth effect of glyphosate at any dose on glyphosate-resistant soybean with an insensitive EPSPS supports this hypothesis (Velini et al. 2008). Low doses of glyphosate are used to enhance sucrose accumulation in sugarcane (Dusky et al. 1986, Su et al. 1992, McDonald et al. 2000). More carbon is partitioned into sucrose when lignification is inhibited (Liu et al. 1997). So, since lignin synthesis is dependent on the shikimic acid pathway, low doses of glyphosate may inhibit lignification sufficiently to allow plant to partition more carbon into sucrose (Velini et al. 2008). Another possible explanation for sugar accumulation at low glyphosate doses might be that glyphosate at low doses preferentially inhibits metabolic activity of meristematic tissues, thereby slowing translocation of sugar to such metabolic sinks. Glyphosate is preferentially translocated to metabolic sinks, in which it is accumulated (reviewed by Duke 1988). Thus, sugar synthesis might not be inhibited in plant leaf tissues with glyphosate concentrations too low to have an adverse effect, while concentrations of glyphosate in meristematic tissues of the same plant might be high enough to stop growth, thereby no longer importing sugar. Perhaps both mechanisms could be involved in glyphosate-enhanced sugar accumulation in sugarcane; however, the latter explanation would not explain glyphosate-caused hormesis in the case of overall growth stimulation. Nevertheless, if lignin synthesis is preferentially 

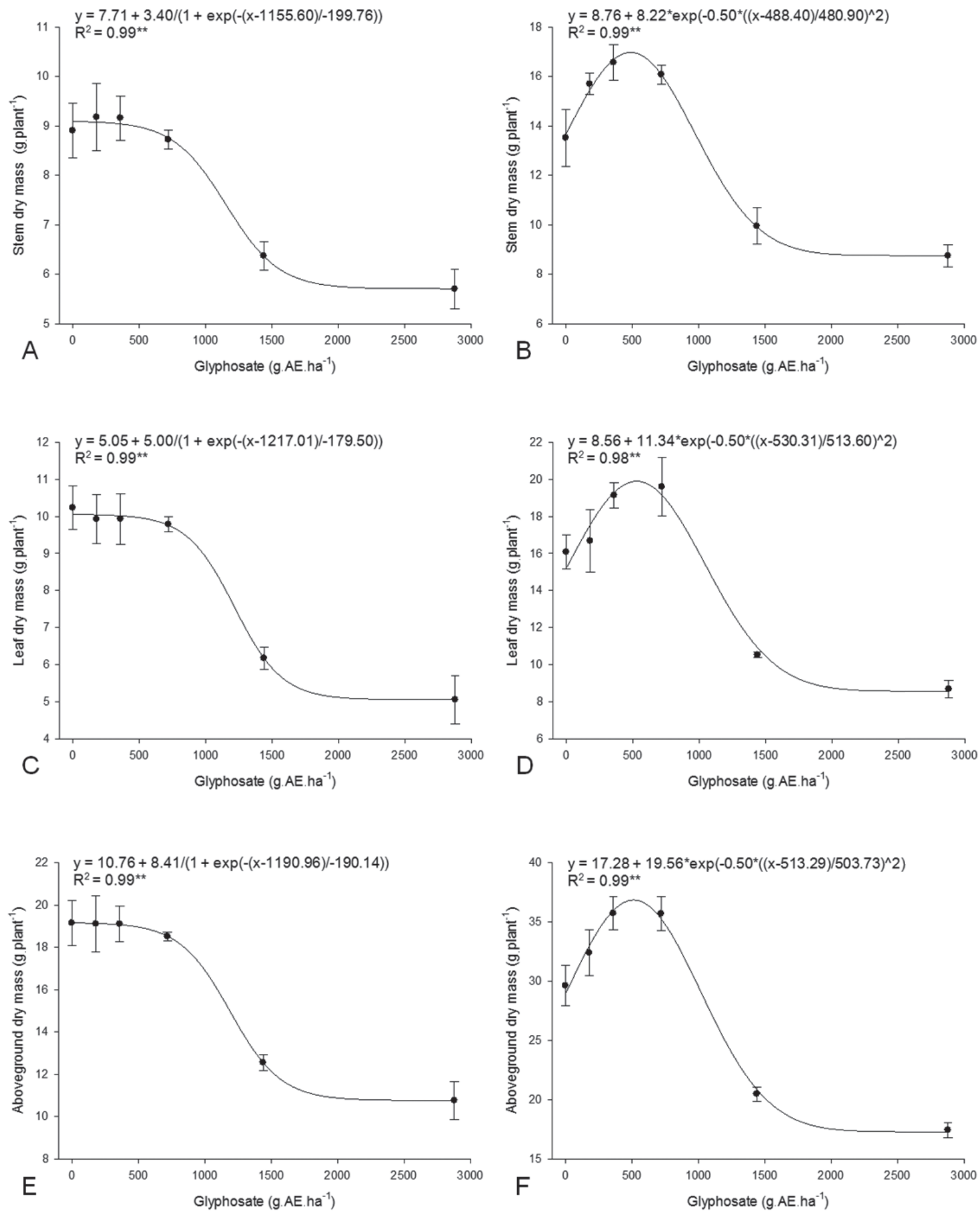

Figure 5 - Coffee stem, leaf and above ground dry mass at 60 days after being exposed to glyphosate applied on plants with 10 (A, C and E) and 45 (B, D and F) days after transplanting. Jaboticabal, 2009-10. Vertical bars indicate standard error of the mean, **significant at $p<0.01$. 
inhibited at low glyphosate doses, cell walls would remain elastic for a longer period, allowing for greater cell expansion, and, thus, enhanced growth. However this mechanism would not explain stimulatory effects on total dry weight.

Other studies have shown that plant growth stimulation by glyphosate is a result of resource allocation to the whole plant (Cedergreen 2008). To achieve the biomass increase, plants must either increase photosynthetic rates or decrease respiration rates in response to the low glyphosate doses (Cedergreen and Olesen 2010). From a theoretical viewpoint, it is unlikely that respiration rates decrease, as addition of xenobiotics usually induces detoxification processes which are energy demanding (Cole 1994, Purrington and Bergelson 1999). So, an increase in photosynthesis rates (by increasing light harvesting and/or efficiency of carbon fixation) could explain the plant growth stimulation (Cedergreen and Olesen 2010).

A single specific physiological mechanism of hormesis has not been found. The finding that glyphosate does not produce hormesis in glyphosateresistant crops indicates strongly that the mechanism requires inhibition of EPSPS (Velini et al. 2008). This suggests that the mechanism of hormesis is dependent on its effects on the shikimate pathway. Since glyphosate is the only phytotoxin known to inhibit the shikimate pathway, the mechanism of hormesis for glyphosate appears to be unique. Whatever the mechanism, our study shows that the hormetic effect can be strongly dependent on the plant growth stage. We could observe the hormetic effect only in plants exposed to glyphosate at 45 DAT, while exposure of younger plants (10 DAT) did not show this growth stimulation. We can only speculate on the age dependency for glyphosateassociated hormesis that we have observed.

Younger plants are almost always more susceptible to herbicides than older plants of the same species. In our study, this is apparent in $\mathrm{I}_{50}$ values mainly for shoot plant height and stem diameter, resulting in a factor of tolerance greater than 1.5 (Table I). At the time of glyphosate application, the youngest plants (10 DAT) had just six leaf pairs and no stem ramifications, whereas the 45 DAT-plants had formed a greater leaf biomass with stem ramifications when the herbicide was applied. Another difference is that the younger plants were sprayed with herbicide exposure only a short period after transplanting, so that they had less time to establish their roots in the substrate. The older plants may have had greater capacity to detoxify glyphosate and less absorption of the herbicide through plants surfaces. They had greater biomass to dilute the herbicide. Furthermore, the ratio of more sensitive meristematic tissues to mature tissues would be smaller in older than younger plants, so that the concentration reaching the meristem would probably be less. There are no data with coffee to support any of these mechanisms, but reduced absorption in older plants has been described in literature with other species. Younger plants usually have a thinner epicuticular wax layer on the leaf epidermis than older ones, although this does not always translate to greater herbicide absorption by younger leaves (e.g., Viougeas et al. 1995). Epicuticular wax layer composition and thickness influences glyphosate penetration through the leaf tissue (Michitte et al. 2007, Nandula et al.

\section{TABLE I}

Dose reducing the growth characteristics by $\mathbf{5 0 \%}\left(\mathbf{I}_{50}\right)$ and the factor of tolerance (FT) of coffee plants exposed to glyphosate at 10 and 45 days after transplanting. Jaboticabal, 2009-10.

\begin{tabular}{lccc}
\hline \multirow{2}{*}{ Characteristics } & \multicolumn{2}{c}{$\mathbf{I}_{\mathbf{5 0}}$ (g.AE.ha ${ }^{-1}$ ) } & \multirow{2}{*}{ FT } \\
\cline { 2 - 3 } & 10 DAT & 45 DAT & \\
\hline Plant height & 1,196 & 1,845 & 1.54 \\
Stem diameter & 557 & 968 & 1.74 \\
Number of leaves & 1,375 & 1,434 & 1.04 \\
Leaf area & 1,064 & 1,307 & 1.23 \\
Stem dry mass & 1,156 & 1,237 & 1.07 \\
Leaf dry mass & 1,217 & 1,335 & 1.10 \\
Aboveground dry mass & 1,191 & 1,298 & 1.09 \\
\hline
\end{tabular}


2008). Since glyphosate is a hydrophilic herbicide, its penetration through thinner epicuticular wax layers may be increased in younger plants.

Because of these factors, more glyphosate is probably reaching EPSPS in 10 DAT-plants than in 45-DAT plants. On the other hand, glyphosate application at high doses can increase its penetration efficiency due to the high differences in herbicide concentrations between the leaf surface and leaf tissues, since diffusion is the main process of glyphosate transport through the plant cuticle (Stahlman and Phillips 1979, Caseley and Coupland 1985). This might explain the similar reduction in plant growth of younger and older coffee plants exposed at higher glyphosate doses.

Only a few studies on effects of glyphosate on coffee plants have been published. Hormesis with glyphosate was not observed in coffee plant growth in a range of doses from 57.6 to 460.8 g.AE.ha ${ }^{-1}$, but a significant reduction in plant height, leaf area, stem dry mass, leaf dry mass, and root density occurred (França et al. 2010a), and reductions in leaf nutrient content were observed (França et al. 2010b). Field observations indicated that effects of glyphosate can persist until harvesting, reducing coffee bean yield (Nelson 2008). Comparing results with others is difficult, because different dose-responses are expected, depending on growth conditions (Belz and Cedergreen 2010) and plant growth stage (Velini et al. 2008). For these reasons, predicting beneficial or stimulatory effects of sub-lethal glyphosate doses under agricultural conditions is very imprecise and it is not likely to be useful in agricultural production (Belz et al. 2011).

The findings presented here show that coffee plants cv. Catuaí Vermelho IAC-144 are tolerant to sub-lethal doses of glyphosate and that low doses of glyphosate can even stimulate growth of the plants if exposure is at the right growth stage. So, reported deleterious effects of glyphosate observed in the field that are attributed to the glyphosate drift may be due to other factors. Further research is needed to evaluate the effects of low doses of glyphosate on plants and to understand the mechanisms involved. Such work is fundamental to improve our knowledge of glyphosate dynamics in production systems and to have precise information about the effects of glyphosate on non-target plants (Velini et al. 2008).

\section{ACKNOWLEDGMENTS}

We would like to thank Conselho Nacional de Desenvolvimento Científico e Tecnológico (CNPq) for the doctorate scholarship provided to the first author.

\section{RESUMO}

Os sistemas de manejo de plantas daninhas em quase todos os pomares de café do Brasil permitem que o herbicida pulverizado sofra deriva sobre a cultura. Com objetivo de avaliar se há algum efeito do glyphosate, herbicida mais comumente utilizado em pomares de café, sobre as plantas de café, uma ampla faixa de doses do herbicida foi aplicada diretamente sobre plantas de café em dois distintos estádios de crescimento da planta. Embora o crescimento de ambas as plantas novas e velhas tenha sido reduzido em doses mais altas de glyphosate, baixas doses não causaram efeitos sobre características de crescimento de plantas novas e estimularam o crescimento das mais velhas. Portanto, o efeito hormético do glyphosate é dependente do estádio de crescimento da planta de café no momento da aplicação do herbicida.

Palavras-chave: Coffea arabica L., manejo de plantas daninhas, herbicida, deriva simulada, efeito estimulante.

\section{REFERENCES}

Belz RG And Cedergreen N. 2010. Parthenin hormesis in plants depends on growth conditions. Environ Exp Bot 69: 293-301.

Belz R, Cedergreen N And Duke SO. 2011. Herbicide hormesis - can it be useful in crop production? Weed Res 51: 321-332.

Bott S, Tesfamariam T, Kania A, Eman B, Aslan N, RoEMHELd V AND Guenter N. 2011. Phytotoxicity of glyphosate soil residues re-mobilized by phosphate fertilization. Plant Soil 342: 249-263.

Calabrese EJ And Baldwin LA. 2002. Defining hormesis. Hum Exp Toxicol 21: 91-97. 
CASELEY JC AND COUPLAND D. 1985. Environmental and plant factors affecting glyphosate uptake movement and acidity. In: GROSSBARD E AND ATKINSON DA (Eds), The herbicide glyphosate. Butterworths, London, UK, p. 92-123.

Cedergreen N. 2008. Is the growth stimulation by low doses of glyphosate sustained over time? Environ Pollut 156: $1099-1104$.

Cedergreen N and Olesen CF. 2010. Can glyphosate stimulate photosynthesis? Pestic Biochem Physiol 96: 140-148.

Cedergreen N, Streibig JC, Kudsk P, Mathiassen SK and DUKE SO. 2007. The occurrence of hormesis in plants and algae. Dose Resp 5: 150-162.

COLE DJ. 1994. Detoxification and activation of agrochemicals in plants. Pestic Sci 42: 209-222.

DUKE SO. 1988. Glyphosate, In: KEARNEY PC AND KAUFMAN DD (Eds), Herbicides-chemistry, degradation and mode of action, Vol. III. Marcel Dekker Inc., New York, p. 1-70.

DUSKY JA, KANG MS, GLAZ B AND MiLLER JD. 1986. Response of eight sugarcane cultivars to glyphosine and glyphosate ripeners. Plant Growth Regul 4: 225-235.

França AC, Freitas MAM, D’Antonino L, Fialho CMT, SILVA AA, REIS MR AND RONCHI CP. 2010b. Nutrient content in arabica coffee cultivars submitted to glyphosate drift. Planta Daninha 28: 877-885.

FranÇa AC, Freitas MAM, Fialho CMT, Silva AA, Reis MR, GALON L AND ViCTORIA FiLHO R. 2010a. Growth of arabica coffee cultivars submitted to glyphosate doses. Planta Daninha 28: 599-607.

FujioKa K And Shibamoto T. 2008. Chlorogenic acid and caffeine contents in various commercial brewed coffees. Food Chem 106: 217-221.

Gravena R, Victoria FilHo R, Alves PlCA, Mazzafera P AND GRAVENA AR. 2009. Low glyphosate rates do not affect Citrus limonia (L.) Osbeck seedlings. Pest Manag Sci 65: 420-425.

HERRMAN KM AND WeAVER LM. 1999. The shikimate pathway. Annu Rev Plant Physiol Plant Mol Biol 50: 473-503.

LiU L, PUnJA ZK AND RAHE JE. 1997. Altered root exudation and suppression of induced lignification as mechanisms of predisposition by glyphosate of bean root (Phaseolus vulgaris L.) to colonization by Pythium spp. Physiol Mol Plant Pathol 51: 111-127.

LYDON J AND DuKE SO. 1989. Pesticide effects on secondary metabolism of higher plants. Pestic Sci 25: 361-373.

MACHAdo AFL, FERreira LR, SANTOS LDT, FERrEIRA FA, VIANA RG, MACHADO MS AND FREITAS FCL. 2010. Photosynthetic efficiency and water use in eucalyptus plants sprayed with glyphosate. Planta Daninha 28: 319-327.

Marana JP, Miglioranza E, FonseCA EP AND Kainuma RH. 2008. Seedling quality in coffee grown in containers. Cienc Rural 38: 39-45.

MCDOnALd LM, MORGAN T AND Kingston G. 2000. Chemical ripeners: an opportunity for the Australian sugar industry. Proc Aust Soc Sugarcane Technol 22: 290-295.
Michitte P, De Prado R, EspinOza N, Ruiz-SANTAELla JP AND GAUVRIT C. 2007. Mechanisms of resistance to glyphosate in a ryegrass (Lolium multiflorum) biotype from Chile. Weed Sci 55: 435-440.

NAIDU MM, SUlochanamma G, SAMPATHU SR AND SRINIVAS P. 2008. Studies on extraction and antioxidant potential of green coffee. Food Chem 107: 377-384.

NANDULA VK, REDDY KN, Poston DH, RIMANDO AM AND DUKE SO. 2008. Glyphosate tolerance mechanism in Italian ryegrass (Lolium multiflorum) from Mississippi. Weed Sci 56: 344-349.

NAscimento EA, Oliveira LEM, CAstro EM, Delú Filho N, MEsquita AC AND VIEIRA CV. 2006. Morphological alterations in leaves of (Coffea arabica L. plants in consort with Hevea brasiliensis Muell. Arg. Cienc Rural 36: 852-857.

NELSON S. 2008. Glyphosate herbicide injury to coffee plants. Available at: http://www.ctahr.hawaii.edu/oc/freepubs/ pdf/PD-56.pdf. p. 1-5. [Accessed Sep. 5, 2011].

Purrington CB AND Bergelson J. 1999. Exploring the physiological basis of costs of herbicide resistance in Arabidopsis thaliana. Am Nat 154: S82-S91.

Schabenberger O, Kells JJ And Penner D. 1999. Statistical tests for hormesis and effective dosage in herbicide doseresponse. Agron J 91: 713-721.

SERVAITES JC, TUCCI MA AND GEIGER DR. 1987. Glyphosate effects on carbon assimilation, ribulose bisphosphate carboxylase activity, and metabolite levels in sugar beet leaves. Plant Physiol 85: 370-374.

SIEHL DL. 1997. Inhibitors of EPSPS synthase, glutamine synthetase and histidine synthesis. In: ROE RM, BURTON JD AND KUHR RJ (Eds), Herbicide Activity: toxicology, biochemistry and molecular biology. IOS Press, Amsterdam, The Netherlands, p. 37-67.

Silva MA, Aragao NC, Barbosa MA, JERONimo EM AND CARLIN SD. 2009. Hormetic effect of glyphosate on the initial development of sugarcane. Bragantia 68: 973-978.

STAHLMAN PWPW AND PHILliPS WM. 1979. Effects of water quality and spray volume on glyphosate phytotoxicity. Weed Sci 27: 38-41.

Su LY, Cruz AD, Moore PH AND MARETZKi A. 1992. The relationship of glyphosate treatment to sugar metabolism in sugarcane: new physiological insights. J Plant Physiol 140: $168-173$.

TufFi SANTos LD, Ferreira FA, FERreira LR, DuArte WM, TIBURCIO RAS AND SANTOS MVV. 2006. Intoxication of eucalypt species under glyphosate drift. Planta Daninha 24: 359-364.

Velini ED, Alves E, Godoy MC, Meschede DK, Souza RT AND DuKE SO. 2008. Glyphosate applied at low doses can stimulate plant growth. Pest Manag Sci 64: 489-496.

Viougeas MA, RoHR R AND ChAmel A. 1995. Structural changes and permeability of ivy (Hedera helix L.) leaf cuticles in relation to leaf development and after selective chemical treatments. New Phytol 130: 337-348.

WAgner R, Kogan M AND PARADA AM. 2003. Phytotoxic activity of root absorbed glyphosate in corn seedlings (Zea mays L.). Weed Biol Manag 3: 228-232. 